\title{
The effect of vertical brand extensions on consumer-brand relationships in South Africa
}

\author{
O. Muroyiwa ${ }^{\mathrm{a}}, \mathrm{R}$. Abratta,b* and M. Mingione ${ }^{\mathrm{c}}$ \\ ${ }^{a}$ Wits Business School, University of the Witwatersrand, Johannesburg, P O Box 98, Wits 2050 South Africa \\ ${ }^{b}$ Huizenga College of Business and Entrepreneurship, Nova Southeastern University, Fort Lauderdale, Florida, USA \\ 'Department of Management and Law, University of Rome, Tor Vergata, Rome, Italy
}

*To whom all correspondence should be addressed

abratt@nova.edu

\begin{abstract}
The purpose of this research is to evaluate the impact of the introduction of vertical brand extensions on Consumer-Brand Relationships (CBRs) in the mobile phone market. In particular, we aim at exploring the effect vertical brand extensions that luxury and functional brands have on consumers' perceptions, as well as the effect the extensions will have on CBRs. This study pursues a quantitative approach, developing and testing four hypotheses on the influence vertical brand extensions have on four CBR-related constructs, namely brand attachment, brand trust, brand commitment and brand identification. The elicited context is the South African market and the selected brands are Apple, to represent luxury brands, and Samsung, representative of functional brands. Results only partially confirm previous research on vertical brand extension. Supporting previous studies, a vertical step-down extension has been found to have a stronger negative impact on brand commitment for the luxury brand than for the functional one. However, findings disconfirm the literature in revealing a stronger negative impact on the functional brand than the luxury brand and a positive effect on the brand attachment of both brands, especially the functional brand.
\end{abstract}

\section{Introduction}

Many companies prefer to launch their new products as brand or line extensions, leveraging already successful brand names (Keller \& Lehmann, 2009) The motive for a brand extension strategy is usually an effort to leverage "previous positive consumer attitudes towards a brand on new products carrying that same brand name" (Dall'Olmo Riley, Pina \& Bravo, 2015: 886). Stretching the brand franchise beyond the current product class is defined as a brand extension, while line extension involves the launch of the product from the same product category or product class under a familiar brand name (Phau, Min Teah, Hanslin \& Rindell, 2014). Brand extensions have also been seen even in the virtual world, where Google has extended from a search engine to new products such as Gmail, Gtalk and Google Plus (Song, Zhang, Xu \& Huang, 2010). The success of brand extensions is related to a set of marketing strategy decisions made by the firm (Athanasopoulou, Giovanis \& Avlontis, 2015).

Line extensions are the most frequent way of introducing new products, thus extending a brand to capitalise on a brand's recognition, and consumer trust may be deemed a proper strategic choice for any firm (Giachetti \& Dagnino, 2014). In this day and age, consumers demand variety and choice (Datta, 1996) and more opportunities now exist for line extensions that have new flavours or sizes. Other brand extensions are premised on small incremental improvements to the already existing product (Claudiu-Cătălin \& DorianLaurenţiu, 2014).
The purpose of this research is to evaluate the impact of the introduction of downward brand extensions on consumerbrand relationships (CBR) in two mobile phone brands in the South African market. It will focus on evaluating the effect that downward extensions of Apple's and Samsung's flagship brands will have on consumer's perception of these brands, as well as the effect the extensions will have on consumerbrand relationships. Thus, key questions to be answered in this study are "What impact does the brand concept (luxury or functional) have on the consumer evaluation of the brand extension?" and "What effect does the brand concept (luxury or functional) have on the consumer-brand relationship post extension?"

With a population of 54 million (Statistics-South Africa, 2014) and a GDP of US\$350.6 billion (World Bank, 2013), South Africa is one of the highest users of mobile technology and social networking on the African continent. Furthermore, South Africa is the lead innovator in Africa for social networking, microblogging and content generation (UNICEF, 2012). As such, South Africa represents a market in which the demand for smartphones is on the rise and manufacturers would do well to tailor their product offerings to the various market segments presented by the diversity of the South African population and its needs, including access to the Internet, new applications, mobile banking and exploration of digital content. To this end, a number of smartphone manufacturers have been distributing a range of smartphone products. These companies include Sony, Samsung, Apple and HTC, among many others. An August 2014 survey of 5,113 users undertaken by the Interactive 
Advertising Bureau of South Africa (IAB) and Effective Measure revealed that $91.7 \%$ of South African Internet users own smartphones (Effective Measure, 2014). The study further revealed that in terms of smartphone brand market share, Samsung is the leader. An analysis of the purchase intentions of smartphone users also revealed that $23 \%$ of these users desired the purchase of a new smartphone within six months and another $16.5 \%$ in less than a year. These findings reveal that there exists within the South African smartphone market, an early adopter consumer group that presents opportunities for smartphone distributors to maximise sales.

The fast pace of technology has made it possible for smartphone manufacturers to present new product offerings almost every year (Roets, Bevan-Dye \& Viljoen, 2014). This evolution of devices is characterised by the variation in products including newer features, new or improved applications or greater device memory. At the same time, extending brands vertically to different price and quality levels is also a popular strategy among brand managers so as to capture as wide a market as possible (Goetz, Fassnacht \& Rumpf, 2014). One of the benefits to the consumer is the possibility of buying a luxury or premium brand of phone at a lower price (Dall'Olmo Riley et al., 2015).

A brand concept has been defined by Torelli, Özsomer, Carvalho, Keh \& Maehle (2012) as being a unique and abstract meaning associated with a brand. They further posit that such meanings may emanate from a distinct combination of features, benefits, attributes and marketing activities. As such, the two brands being analysed will be classified under the following concepts: luxury or prestige (Apple) and functional (Samsung). Despite the debate as to the true definition of a 'luxury' brand in the literature, according to Atwal and Williams (2009) a luxury brand is one whose natural evolution is characterised by the luxury brand first being adopted by the affluent and wealthy before inevitably being translated and reinterpreted down to mass markets. Luxury brands are generally associated with exclusivity, status and quality. Phau and Prendergast (2000) indicate that a luxury brand elicits exclusivity, has a famous brand identity and enjoys very high brand awareness and perceived quality. Furthermore, in the South African smartphone market, Apple only commands a $14.1 \%$ market share due to the pricing structure and numerous studies have revealed that South Africans generally find the iPhone to be quite expensive (Effective Measure, 2014). It is for these reasons that Apple was used as the luxury or prestige brand.

We proceed as follows. Firstly, we review the literature that informs this study and then develop four hypotheses. Secondly, we describe the research methodology and design. Thirdly, the results are presented followed by a discussion. Lastly, we give some conclusions and make recommendations for brand management.

\section{Theoretical framework}

\section{Brand extensions}

The manner in which companies increase or decrease their product lines, is one of the strategic directions a company can take in order to keep up with the competitive intensity within that particular industry (Giachetti \& Dagnino, 2014). One of the ways that firms increase their product lines is via brand extension. Brand extension is when a company uses an already established brand name to introduce new products and services (Aaker \& Keller, 1990). Firms thus engage in brand extension strategies with the goal of benefiting from the brand knowledge already garnered in their existing markets (Vukasovič, 2012).

Brand extensions are a vital strategy for many new product and service launches as the use of an established brand can increase faster acceptance and adoption of the new offering. Furthermore, the huge costs and risks incurred in launching new brands, many of which fail, has necessitated many companies choosing to extend their brands (Ambler and Styles, 1996). This in essence minimises the risk associated with new product launches (Albrecht, Backhaus, Gurzki \& Woisetschläger, 2013). Furthermore, the introduction of other products under the same brand name may result in a positive perception of the core brand. This may be a result of consumers perceiving the variety of products to denote the firm's competence in that product area (Goetz et al., 2014). Moreover, the stocking of many products from a particular brand by retailers increases the visibility of the brand and consumers' attention towards it.

\section{Line extensions}

Line extensions denote the launch of new products from the same product category or product class under a familiar brand name (Nijssen, 1999). Due to the risk inherent in the launching of a new brand, firms may prefer to extend their brands vertically across varying price and quality levels. Thus, brands can be extended upwards or downwards.

Vertical-line extensions are premised on the differentiation of quality and consequently price levels within a product category (Randall, Ulrich \& Reibstein, 1998). A crucial strategic decision is the need to maintain or raise revenue by aiming for a wider consumer segment with products that are priced lower or focussing on smaller niche target groups that exhibit a high level of willingness to pay for a more expensive product (Goetz et al., 2014). Kotler (2009) further argues that proliferated product lines do benefit the dominant brands in particular through market expansion that will enable them to capture higher levels of variety-seeking customers.

By initiating upscale extensions, firms signal great brand quality while downscale extensions can attract hitherto unexplored market segments as these downscale extensions may appeal to the mass market. Downscale extensions are particularly important for the firm in that the core target is enlarged, sales volumes increase and the firm is able to sell a 
higher number of affordable products using the same name (Magnoni \& Roux, 2012) and as a result, enhance the brand's diffusion in the market (Dens \& De Pelsmacker, 2015).

\section{Brand evaluations after extension}

Despite the popularity of line extensions as a strategy to enhance growth in both the fast moving consumer goods and luxury brand arenas (Dall'Olmo Riley, Pina \& Bravo, 2013), extant research has mainly focussed on the evaluation of the core or parent brand after category extensions. As a result, the most dominant factors established in the literature as the key features that consumers regard when evaluating brand extensions are fit perceptions and brand associations (Aaker $\&$ Keller, 1990). These studies have revealed that there can be negative and positive consequences of an extension strategy. Brand extension evaluations by a consumer are usually described by a transfer process in which core brand associations are conveyed to the extension (Pitta \& Prevel Katsanis, 1995). These consequences arise because extensions may establish new perceptions in a consumer's mind that may enhance or negatively impact on prior perceptions that consumers had of the brand (Pina, Martinez, De Chernatony \& Drury, 2006). A vertical brand extension involves extending a product to a different level of quality or price either upwards or downwards; one can therefore perceive that since quality is an integral part of both functional or prestige oriented brands, it is plausible that functional and luxury oriented brands may be affected in differing ways by vertical brand extensions. Furthermore, brand extensions may affect the quality of the CBR.

\section{Downward (downscale) extension evaluation}

A downward extension is an extension that is introduced at a lower price and quality level than its core brand and is usually targeted at segments of the market that are willing to spend on, or can only afford, the basic or minimised version of the current product ( Dall'Olmo Riley et al., 2013). Downward extension strategies have been necessitated by consumer trends, in which buyers have turned away from prestige and luxury brands, to brands that deliver acceptable quality and features, albeit at a low cost (Rahman \& Areni, 2014). To ward off these phenomena, firms are offering "lesser" or "mini" versions of their traditional products and brands, meeting the necessities of the value market (Kirmani, Sood \& Bridges, 1999). This phenomenon, particularly in the luxury goods sector, is targeted towards a younger market and driven by the perceived potential of a firm's global volume growth post-extension.

Given that a downward extension is offered at a lower price than the core brand, there is a risk that sales of the main product may be reduced as consumers opt for the lower priced product, particularly if consumers feel that the only differentiator is price and not the quality (Kim \& Lavack, 1996; Liu, 2002). This can lead to a forsaking of the core product. An additional risk is that the core brand could be associated with low quality, which may in turn affect consumer evaluations of a firm's entire product portfolio.
Maintaining the brand's perception of prestige and exclusivity may be hampered if a downscale extension that targets the lower-end consumer market is introduced (Kim \& Lavack, 1996). This is particularly so for luxury brands where the introduction of a downward extension may result in negative feedback effects among the brands' original consumers. The original clientele may resent the step-down extension as it lowers the social status and prestige they would normally associate with their prestigious acquisition.

\section{Upward (upscale) extension evaluation}

Through a upward or upscale extension, a superior or premium version of the product is used to target the high-net worth end of the market (Dall'Olmo Riley et al., 2013). Stepup extensions are usually motivated by attractive growth segments that provide higher profits and are normally denoted by a descriptor, e.g. premium, gold, reserve, limited, exclusive etc., in order to attract a higher end market (Rahman \& Areni, 2014).

According to Munthree, Bick and Abratt (2006), an upscale extension may lead to the revitalisation of a brand if the positioning and credibility of the new product are sufficient. Furthermore, as upscale extensions signal greater quality (Goetz et al., 2014), they may also help to enhance the prestige of the brand at all levels of price and quality (Randall et al., 1998). An example is how the prestige of Mercedes is transmitted and persists across all of its models. There is, therefore, a belief within customers of a trickle-down of quality from the high end products to the non-premium models. However, the introduction of a brand extension may affect the core brand, particularly when the core brand has not been associated with greater quality before (Kim and Lavack, 1996; Randall et al., 1998).

Extant research has also revealed both positive and negative evaluations of parent brands in the aftermath of an upscale extension, as well as neutral and negative core brand evaluations after downscale extensions (Goetz et al., 2014). Negative evaluations have also been noted in either of the extension directions.

\section{Consumer-brand relationships (CBRs)}

A consumer-brand relationship (CBR), is the relationship that customers think towards, feel and experience with a brand (Fournier, 1998). The relationships that exist between consumers and brands are crucial for the long-term success of any business (Tuškej, Golob \& Podnar, 2013). In this day and age, characterised by conspicuous consumption (Sundie, Kenrick, Griskevicius, Tybur, Vohs \& Beal, 2011), individuals are increasingly searching for new avenues and opportunities in their lives to find objects or passions that can fill them with meaning.

This desire is often satisfied by consuming material products or possessing such beloved objects (Bauer, Heinrich \& Martin, 2007). In this way then, consumers establish relationships with brands that are self-expressive. Carroll and 
Ahuvia (2006) define self-expressive brands as those brands that consumers see as a means to enhance themselves socially and a way to express their inner self. Brand relationships can lead to brand resonance, a concept put forward by Keller (2001) to characterise CBRs. Brand resonance refers to the nature of the CBR and, more specifically, the extent to which a person feels that he or she resonates or connects with a brand and feels "in sync" with it. As such over time, scholars have thus come up with a number of CBR constructs which are in themselves a function of the levels at which consumers engage or interact with brands, and the resultant activity and level of intensity of the relationships (Keller, 2014). These constructs are brand trust (Delgado-Ballester, MunueraAleman \& Yague-Guillen, 2003), brand identification (Stokburger-Sauer, Ratneshwar \& Sen, 2012), brand commitment (Albert, Merunka \& Vallette-Florence, 2013), brand love (Fetscherin \& Heinrich, 2014), as well as brand passion (Albert et al., 2013).

\section{Hypotheses development}

The relationship between a brand and its consumers can be affected by brand extensions. The brand relationship quality can be enhanced or diluted by the actions of the consumer or by the brand itself. This is derived from the "reciprocity principle of all relationships" (Magnoni \& Roux, 2012: 598). As such, vertical extensions may affect some variable constructs of CBR, such as brand identification, brand attachment, brand trust and brand commitment.

\section{Brand identification}

Brand identification is defined as the measure by which a consumer will perceive their self-image as being the same as the image of the brand (Tuškej et al., 2013). The construction of an individual's personal identity in part contributes to the use of brands whose user image is congruent to that consumer's self-image. Therefore since an identity may be constructed and the individual able to self-express via a brand, a relationship may be built between the brand and the consumer (Kuenzel \& Halliday, 2010). Furthermore, where a good can be consumed in public, particularly so for luxury brands, these luxury goods thus provide an avenue through which the individual can find themselves (Sundie et al., 2011).

Vertical brand extensions enable the brand to seek out new market segments. Once extended, the brand may have another set of associations attached to it that may be different from what the current typical consumer of that brand has been experiencing. Downward extensions may, due to their lower prices, be viewed as inconsistent and incompatible to the dominant view of a luxury brand as a status symbol that may be held in the minds of consumers (Desai \& Hoyer, 1993). This is because a downward extension broadens the target market, making it more democratic, in essence reducing the exclusivity of the brand and, as a result, the consumers' need for uniqueness is no longer satisfied (Magnoni \& Roux, 2008). Consequently, it is expected that a downward brand extension weakens brand identification leading to Hypothesis 1.

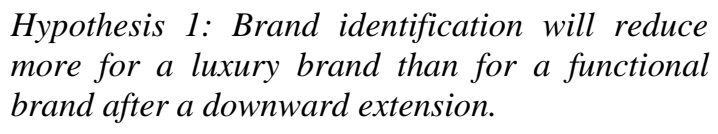

Hypothesis 1: Brand identification will reduce more for a luxury brand than for a functional brand after a downward extension.

\section{Brand attachment}

Aaker (1997) defined brand attachment as the firm's emotional ties that link a consumer with a brand. Beyond mere sensory stimulation, a brand can induce positive or negative moods and enable consumers to feel joyful and happy, or angry and sad (Schmitt, 2012) . These feelings or emotions may influence a consumer's level of attachment to the brand. Brand attachment is a precursor for other attributes such as brand commitment and brand loyalty (Japutra, Ekinci \& Simkin, 2014; MacInnis, 2012) and is crucial to the development of quality brand relationships over time. As can be drawn from the study of human relationships (Fournier \& Yao, 1997), the stronger one's attachment to an object, the more likely the individual is to attain or retain proximity to the target of his/her attachment (MacInnis, 2012). Therefore, consumers with great brand attachment are more likely to repeat purchase a good. Extant literature has revealed that a downward extension can weaken the perception of a core brand (Kim, Lavack \& Smith, 2001), while Magnoni and Roux (2012) discovered that the introduction of a downward line extension generates a reduction in brand attachment in luxury brands. This is because the availability of the brand to a higher number of consumers leads to massification and democratisation of the luxury (Nueno \& Quelch, 1998). It is therefore proposed that a downward extension will also weaken brand attachment hence Hypothesis 2 .

\section{Hypothesis 2: Brand attachment will reduce more in a luxury brand, as compared to a functional brand, after a downward extension.}

\section{Brand trust}

Sahin Zehir and Kitapçı (2011) define brand trust as the confident belief that a consumer has that he or she can depend on the brand to deliver the promised service. DelgadoBallester et al. (2003) describe trust as being two-dimensional and possessing attributes of reliability and intentions. Reliability denotes the technical aspects of the brand and ability to perform its task, while intention is the ability of the brand to act in the best interests of the consumer. Maintenance of brand associations linked to prestige and exclusivity may be challenging where the company initiates downward extensions that target the lower spectrum of the market (Randall et al., 1998). Brand extension strategies can thus affect brand trust, more so in luxury brands, which can be detrimental as brand trust is a key element which should be maintained for a stable and durable relationship (Magnoni \& Roux, 2008).

A downscale extension, by definition introduces lower levels of quality and should this reduced quality level disappoint 
customer expectations, then consumers will lose trust in the product or brand (Magnoni \& Roux, 2012). The reliability of the brand, which is an important facet of brand trust, has been found to be affected negatively by downscale extensions. Being accessible to a wider market audience may lead to current customers questioning the brand's intention to maintain exclusivity or currently existing brand meanings, hence lowering the intended dimension of brand trust. As a result, it is proposed that a downward extension will lessen brand trust hence Hypothesis 3.

\section{Hypothesis 3: A downward extension will reduce brand trust more for a luxury brand than a functional brand.}

\section{Brand commitment}

Brand commitment may be defined as the level to which a brand may be entrenched in the mind of a consumer as being the only worthy acceptable selection in a particular product class (Warrington \& Shim, 2000). Brand commitment can be also viewed as the behavioural intention (implicit or explicit) to continue a relationship with a brand. As such, high brand commitment like any construct of CBRs, is premised on the ability and success of the firm to establish brand meanings (Sahin et al., 2011). Commitment may be expressed by a consumer's desire to pay a premium price for the product and this commitment may be diminished if the consumer perceives the brand, (as a relationship partner) to have changed. The commitment displayed by a consumer to a product can thus be altered if the brand meanings are also changed. Therefore brand commitment may also be reduced following a downscale extension hence Hypothesis 4 .

Hypothesis 4: A downward extension will reduce brand commitment more for a luxury brand than for a non-luxury brand.

\section{Methodology}

The methodology chosen for this study was a quasiexperimental study (Magnoni \& Roux, 2012). Mobile phones were selected as the product category. After a pre-test among a sample of Masters students, the Apple iPhone 6 as the luxury brand and Samsung Galaxy S6 as the functional brand were chosen as the product brands. Two fictitious downward line extensions were formulated; the Apple iPhone6-mini and the Samsung Galaxy S6-mini. The "mini" concept is one both brands have tried before, albeit in different products, with Apple making the iPad mini and Samsung making mini versions of its S3 and S4 smartphones, i.e. the S3 mini and S4 mini. This aided the experimental design by exposing the respondents to credible possibilities.

Furthermore, respondents were presented with the price of the parent and extension as well as the decreased features (proxy for decreased quality) in the downward extension (Dall'Olmo Riley et al., 2015). The price percentage disparity between the iPad mini and the standard iPad was used in determining the percentage by which the price of the iPhone 6 was compared to that of its mini version. For Samsung, the price differential between the $\mathrm{S} 4$ and its mini version was used to determine at what price the S6 mini fictional extension could be set. The advantage of using such an approach is that actual market percentage price differences were used. In a way this was reflective of the kind of margins and price differentials Apple and Samsung would want to use if they ever considered step-down extensions of their flagship brands.

The population was all individual smartphone users in South Africa. The sample employed in this study is a convenience sample of postgraduate students from a Business School in Johannesburg, South Africa, most of whom are working professionals. The students emanated from different racial and social backgrounds and were thus fairly representative of the typical demography of smartphone users in South Africa.

The information for this study was obtained by means of a questionnaire that was generated via Qualtrics software and e-mailed to respondents. The questionnaire employed sevenpoint Likert scales to measure all constructs. The study adopted a questionnaire that was used by Magnoni and Roux (2012) and translated into English by two French speakers. The two English translations were compared and found to be the same. Brand trust was measured using a scale of four items that measured the credibility dimension of trust, while brand attachment was measured using four items. Brand identification was measured using four items from the scale of Escalas and Bettman (2003, 2005) and brand commitment was measured via five items, three of which were adapted from the scale of Morgan (1991).

An e-mail detailing the scope of the research was sent to each respondent, explaining the objectives of the research and the expected time the questionnaire may take to complete, as well providing a guarantee of confidentiality. A link was also provided that the respondents could use to access the online survey.

SAS 9.3 was used for the analyses. Exploratory factor analysis (EFA) and confirmatory factor analysis (CFA) were employed to assess the measurement model. CFA was initially conducted to test the validity of the four constructs under investigation but only three constructs viz: trust, attachment, and commitment, could be retained for further analysis. An EFA was then performed on the data and it also revealed that the same three constructs could be investigated as analysis revealed only three meaningful factors. Paired ttests were performed to measure the mean of the differences of each construct before and after the step-down extension.

To increase the external validity, a sample that is representative of the South African demographics and general users of smartphones of the brands was chosen. Furthermore, actual users and purchasers of the two brands being studied were used as these give accurate experiences and perceptions of vertical extensions and the current relationships they have with these brands. In order to establish internal validity, closed questions were used as this enabled comparability of the answers. EFA was applied to the responses of both the "before" and "after" sections of the questionnaire. The maximum likelihood method was used to extract the factors, 
and this was followed by a varimax rotation, as recommended by Lee (2015). Therefore, the EFA analyses carried out on both the "before" and "after" sections of the questionnaire revealed that only three constructs (trust, attachment and commitment) could be validated by the data hence brand identification, as a construct, was no longer investigated in this study.

\section{Results}

\section{Profile of sample}

A total of 120 respondents started the survey but only 104 were usable due to incomplete details. Of the respondents, $57 \%$ were male $43 \%$ female; $56 \%$ were Samsung users and $44 \%$ Apple users. They were all reading for a Master of Business Administration, Master of Management or Postgraduate diploma in Business Administration.

\section{Model and hypotheses results}

The model was validated by means of CFA. The results were satisfactory as the fit indicators did substantiate the measurement properties of the model. While each of the fit indicators gives a measure of the model's goodness of fit, these were interpreted together to determine the model's fitting to the observed data. Before the brand extension the chi-square obtained was 77.382, the RMSEA was .1122 and the CFI was .911. After the extension the chi-square obtained was 55.443, the RMSEA was .0059 and the CFI was .956.

Estimates of internal consistency of the research instrument, as measured by Cronbach's alpha, were good. Before the extension, the scores were 0.83 for brand trust, 0.87 for brand attachment, and 0.84 for brand commitment and after the extension they were $0.84,0.87$ and 0.79 respectively.

Hypothesis testing was achieved by means of a paired t-test, comparing the means of each construct (as directed by CFA results) before and after brand extension.

The tests for the effect of the brand extension on brand identification could not be performed as brand identification could not be validated by the model as a stand-alone construct.

The tests for the effect of the brand extension on brand attachment revealed an increase in brand attachment for both brands and these are illustrated in the test outputs in Error! Reference source not found. 1 .

Despite the increase in brand attachment for both brands after the extension, the greater and statistically significant increase is observed in the non-luxury brand, Samsung ( $p=0.0003)$. The increase in attachment for the luxury brand, Apple, is not significant as the observed $p$ value $(0.2354)$, is greater than 0.1 . The results therefore do not support Hypothesis 2 as the brand extension resulted in no significant change in attachment for the luxury brand but instead a significant increase in attachment for the non-luxury brand.
Table 1: Effect of downward brand extension on brand attachment

\begin{tabular}{lccc}
\hline Variable & $\begin{array}{c}\text { Brand } \\
\text { Concept }\end{array}$ & $\begin{array}{c}\text { Luxury } \\
\text { (Apple) }\end{array}$ & $\begin{array}{c}\text { Non- } \\
\text { Luxury(Samsung) }\end{array}$ \\
\hline \multirow{2}{*}{ Brand } & Mean & 0.3889 & 12,105 \\
Attachment & $\mathrm{t}$ Value & 1.2 & 3.89 \\
& $\mathrm{Pr}>|\mathrm{t}|$ & 0.2354 & 0.0003 \\
\hline
\end{tabular}

The tests for the impact of the brand extension on brand trust revealed that brand extension damages trust for both brands, as indicated by the test outputs in Error! Reference source not found. 2 .

The decrease in brand trust in the two brands was statistically significant as observed $\mathrm{p}$ values were less than 0.1 . However, the decrease in trust in the luxury brand was not greater than the decrease in the non-luxury brand, therefore these results do not support Hypothesis 3; the brand extension did not result in a significant negative impact on the luxury brand more than the non-luxury brand.

Table 2: Effect of downward brand extension on brand trust

\begin{tabular}{lccc}
\hline Variable & Brand Concept & $\begin{array}{c}\text { Luxury } \\
\text { (Apple) }\end{array}$ & $\begin{array}{c}\text { Non-Luxury } \\
\text { (Samsung) }\end{array}$ \\
\hline \multirow{3}{*}{ Brand Trust } & Mean & -0.5907 & -0.7982 \\
& $\mathrm{t}$ Value & -4.72 & -5.85 \\
& $\mathrm{Pr}>|\mathrm{t}|$ & $<.0001$ & $<.0001$ \\
\hline
\end{tabular}

The tests for the effect of a brand extension on brand commitment revealed a decrease in commitment towards both brands after extension, as shown in Table 3.

As expected, the greater decline in brand commitment was observed in the luxury brand Apple and was statistically significant $(p=0.0178)$. The decline in brand commitment for the non-luxury brand Samsung was not statistically significant $(p=0.1801)$. These results therefore do support hypothesis 4 , i.e. a downward extension causes a stronger and significant decline in brand commitment for a luxury brand than for a non-luxury brand.

Table 3: Effect of downward brand extension on brand commitment

\begin{tabular}{lccc}
\hline Variable & $\begin{array}{c}\text { Brand } \\
\text { Concept }\end{array}$ & $\begin{array}{c}\text { Luxury } \\
\text { (Apple) }\end{array}$ & $\begin{array}{c}\text { Non-Luxury } \\
\text { (Samsung) }\end{array}$ \\
\hline \multirow{2}{*}{ Brand } & Mean & -0.2130 & -0.1535 \\
Commitment & $\mathrm{t}$ Value & -2.46 & -1.36 \\
& $\mathrm{Pr}>|\mathrm{t}|$ & 0.0178 & 0.1801 \\
\hline
\end{tabular}

\section{Discussion}

Impact of downward extension on brand attachment

There was no significant change in brand attachment for the luxury brand, Apple (despite a slight increase), while for the non-luxury brand, Samsung, there was an increase in 
attachment. These results do not support the literature in which there are usually neutral to negative results for brand attachment after a step-down extension (Kim et al., 2001; Kirmani et al., 1999; Magnoni \& Roux, 2012). However, brand attachment may have increased in part, due to parent brands associated with high quality tending to have a positive effect on the evaluation of downscale extensions, improved CBRs and a perceived value for money. Both Apple and Samsung are leading and possibly the most recognisable mobile phone brands in South Africa, and therefore may be associated with high quality leading them to be viewed more positively after the introduction of brand extensions.

Brand attachment could have also increased for both Apple and Samsung perhaps in part due to their high levels of brand equity. This could have arisen from the use of the two brands' latest and flagship products that consequently were commanding the highest retail prices within their respective categories at the time of the study. As such, if respondents were not users of the flagship brand perhaps in part due to not being able to afford the flagship, then the downscale extensions would have presented an opportunity for them to afford a "toned down" version hence attachment to the brand could increase. Affordability effects, therefore, could have impacted on this study and further research may be needed to look at CBRs from the viewpoint of users of the actual product being targeted for extension (in this case iPhone 6 and Galaxy S6 users only) and not necessarily general users of these brands.

Brand attachment increased for Samsung and this may be because it is a strategy Samsung has employed before within this category of products (mobile phones) with its S3 and S4 mini phones. This result supports Shine Park and Wyer Jr. (2007) who point out that consumers evaluate an extension and consequently the brand more favourably when accompanied by another extension. It may, therefore, be that perhaps the consumers surveyed in the study have been exposed to previous Samsung downward brand extensions or are indeed current users of the same and as such would view another downward extension more favourably.

Extant literature reveals that brand attachment can predict consumer behaviours with one of the consequences of attachment to a brand being consumer willingness and intention to recommend the brand and generate positive word of mouth (WOM). Therefore the introduction of a brand extension could have increased attachment, as respondents who are already users of the brand could have seen the opportunity to spread positive WOM about the brand and an opportunity to recommend the brand to friends who may not be using the brand at present.

A final potential reason for this unexpected result might also be linked to the specific context of this research. Consumers might appreciate the companies' effort to offer different versions of the same brand, because it demonstrates that their product brands are innovative, as required by the quest for constant evolution, typical of the technological sector.

\section{Impact of step-down extension on brand trust}

There was a significant decrease in brand trust for both brands after the extension. This reveals that for luxury and nonluxury brands, vertical brand extension damages trust. A downscale extension, by definition, introduces lower levels of quality and therefore should this reduced quality level disappoint customer expectations, then consumers will lose trust in the product or brand.

Paradoxically, the decrease in trust was however greater for the non-luxury brand than the luxury brand - opposite to the findings of Magnoni and Roux (2012) who noted a decrease in trust for a luxury brand and no effect on trust on the nonluxury brand. The logical assumption and hypothesis that brand trust would weaken more in a luxury brand than in a functional brand could therefore not be supported.

The results, therefore, indicate that for both brands in this category (mobile phones), downscale brand extension can damage brand trust. The decrease in trust for the non-luxury brand may be because as a functional brand, it risks being diluted more quickly and it is harder to maintain prestige at a lower price, while a luxury brand such as Apple in this category has more room to play (Dall'Olmo Riley, Pina \& Bravo, 2011) and can maintain its prestige and brand image over a longer price and quality continuum. Another dimension to explain the change in brand trust is the underlying brand relationship quality. Consumers with a strong brand relationship quality usually have stronger and more favourable reviews of brand extensions (Kim, Park \& Kim, 2014).

\section{Impact of downward extension on brand commitment}

Brand commitment was damaged for the luxury brand Apple but was not affected for the non-luxury brand Samsung, supporting the hypothesis that brand commitment decreases more in a luxury brand than in a functional brand.

Brand commitment can be affected where brand meanings have been altered; it is premised on the ability and success of the firm in establishing brand meanings (Sahin et al., 2011). The introduction of the step-down extension could therefore have been perceived as having changed the meaning of the Apple brand. Its hitherto status as a brand of exclusivity and luxury afforded by a select few would have been damaged by the introduction of a downward extension.

In addition, brand commitment is marked by a consumer willingness to pay a premium for a product. It is plausible that consumers of Apple may have viewed the extension as making the iPhone more available to a general population, hence reducing the exclusivity that the brand offered to consumers. Consequently, consumers no longer exhibit a desire to pay a premium for the brand. This decrease in commitment can be attributed to the consumer viewing that Apple (as a relationship partner) has changed and therefore the consumer cannot commit to the brand as before. 
Extant literature has revealed that for luxury brands, despite having a greater capacity to be stretched, their downscale extensions can have negative effects and unfavourable reactions in product categories where the consumption of a cheaper good is evident - even if the evaluation of the parent brand is unchanged (Dall'Olmo Riley et al., 2013). Mobile phones are a good which is used publicly and therefore Apple users could have had their commitment reduced as a "miniversion" would not carry the same weight and prestige among peers and therefore commitment to the brand was reduced. Consequently, the consumer need for uniqueness is no longer satisfied (Magnoni and Roux, 2008) in the downward extension and therefore commitment is reduced.

\section{Conclusion}

The downscale brand extension of mobile phones led to a deterioration of trust in both the luxury and functional brand with a surprisingly greater reduction in trust in the latter, while brand commitment was significantly reduced only for the former. Our study also revealed that downscale extensions increase attachment to the non-luxury brand while attachment to the luxury brand was unaffected.

\section{Recommendations and managerial implications}

Most literature characterises downward extensions as risky strategies that brands should steer clear of. However, from the results of this study, it is evident that downward brand extension does not necessarily hamper all aspects of the CBR. Furthermore, the risk of downscale extensions is not the same in all product categories and therefore it behoves managers to find a way of ensuring success within their particular categories.

First, managers should initiate brand extensions in brands where a strong brand relationship quality (BRQ) exists. If a strong BRQ exists, consumers are likely to welcome and accept it. Second, managers should be aware that there exists a niche market for step-down extensions for luxury goods, particularly in emerging markets where consumer spending and incomes are low and only a small upper-income market exists. The middle class segments that cannot afford the highly priced core brands may enthusiastically welcome stepdown extensions as has been evidenced by the increase in brand attachment post-extension. Furthermore, profits from the larger middle class may be greater than the profit potential from the small wealthy segment. Third, as extant literature has revealed that satisfaction and communication are antecedents of brand trust. It is crucial that managers explain the extension to both the current customers - so as not to alienate them - and to the potential niche market targeted by the extension. This provision of information reduces consumer uncertainty regarding brand extension and brand strategy.

The study also highlights the need for managers to build strong CBRs as this forms the bedrock upon which loyalty and repeated purchases are based. Brands must be managed to strategically incorporate all facets of the CBR and anticipate how an extension may harm or improve the relationship. This also helps managers to justify investments in marketing activities that intensify and cement the bond between consumers and their brands. Brand managers should also consider measures to capture the different dimensions of CBRs and portray them in their marketing strategies.

\section{References}

Aaker, D.A. 1997. 'Should you take your brand where the action is?', Harvard Business Review, 75(5): 135-143.

Aaker, D.A. \& Keller, K.L. 1990. 'Consumer evaluations of brand extensions', The Journal of Marketing, 54(1): 27-41.

Albert, N., Merunka, D. \& Valette-Florence, P. 2013. 'Brand passion: Antecedents and consequences', Journal of Business Research, 66: 904-909.

Albrecht, C.M., Backhaus, C., Gurzki, H. \& Woisetschläger, D.M. 2013. 'Drivers of brand extension success: What really matters for luxury brands', Psychology \& Marketing, 30(8): 647-659.

Ambler, T. \& Styles, C. 1996. 'Brand development versus new product development: Towards a process model of extension decisions', Marketing Intelligence \& Planning, 14(7): 10-19.

Athanasopoulou, P., Giovanis, A.N. \& Avlonitis, G.J. 2015. 'Marketing strategy decisions for brand extension success', Journal of Brand Management, 22(6): 487-514.

Atwal, G. \& Williams, A. 2009. 'Luxury brand marketing - The experience is everything!', Journal of Brand Management, 16(5): 338-346.

Bauer, H.H., Heinrich, D. \& Martin, I. 2007. How to create high emotional consumer-brand relationships? The causalities of brand passion. Paper presented at the 2007 Australian \& New Zealand Marketing Academy Conference Proceedings.

Carroll, B.A. \& Ahuvia, A.C. 2006. 'Some antecedents and outcomes of brand love', Marketing Letters, 17(2): 79-89.

Claudiu-Cătălin, M. \& Dorian-Laurenţiu, F. 2014. 'Radical brand extensions and consumer profile - A new perspective on innovation and consumer innovativeness', Procedia-Social and Behavioral Sciences, 109: 108-112.

Dall'Olmo Riley, F., Pina, J.M. \& Bravo, R. 2011. Step-down vertical brand extensions of luxury and prestige car brands: exploratory results. Retrieved from http://eprints.kingston.ac.uk/ 19799/1/Riley-F-D-19799.pdf

Dall'Olmo Riley, F., Pina, J.M. \& Bravo, R. 2013. 'Downscale extensions: Consumer evaluation and feedback effects', Journal of Business Research, 66(2): 196-206.

Dall'Olmo Riley, F., Pina, J.M. \& Bravo, R. 2015. 'The role of perceived value in vertical brand extensions of luxury and premium brands', Journal of Marketing Management, 31(7/8): 881-913.

Datta, Y. 1996. 'Market segmentation: An integrated framework', Long Range Planning, 29(6): 797-811. 
Delgado-Ballester, E., Munuera-Aleman, J.L. \& Yague-Guillen, M.J. 2003. 'Development and validation of a brand trust scale', International Journal of Market Research, 45(1): 35-54.

Dens, N. \& De Pelsmacker, P. 2015. 'Does poor fit always lead to negative evaluations? Extension advertising and perceived brand quality', International Journal of Advertising, 35(3): 465-485.

Desai, K.K. \& Hoyer, W.D. 1993. 'Line extensions: A categorization and an information processing perspective', Advances in Consumer Research, 20(1): 599-606.

Effective Measure. 2014. South Africa mobile report: A survey of desktop users attitudes and uses of mobile phones. Retrieved from http://www.sabc.co.za/wps/wcm/connect/68746d0043a866399d42f da602140f6d/South_Africa_Mobile_Report-ar14.pdf?MOD= AJPERES\&CACHEID=68746d0043a866399d42fda602140f6d.

Escalas, J. \& Bettman, J.R. 2003. 'You are what they eat: The infulence of reference groups on consumers' connections to brands', Journal of Consumer Psychology, 13(3): 339-348.

Escalas, J. \& Bettman, J.R. 2005. 'Self-construal, reference groups, and brand meaning', Journal of Consumer Research, 32(3): 378389.

Fetscherin, M. \& Heinrich, D. 2014. 'Consumer brand relationships: A research landscape', Journal of Brand Management, 21(5): 366371.

Fournier, S. 1998. 'Consumers and their brands: Developing relationship theory in consumer research', Journal of Consumer Research, 24(4): 343-353.

Fournier, S. \& Yao, J.L. 1997. 'Reviving brand loyalty: A reconceptualization within the framework of consumer-brand relationships', International Journal of Research in Marketing, 14(5): 451-472.

Giachetti, C. \& Dagnino, G.B. 2014: 'Detecting the relationship between competitive intensity and firm product line length: Evidence from the worldwide mobile phone industry', Strategic Management Journal, 35(9): 1398-1409.

Goetz, D.M., Fassnacht, M. \& Rumpf, K. 2014. 'Extending downward is not always bad: Parent brand evaluations after brand extension to higher and lower price and quality levels', Journal of Brand Management, 21(4): 303-324.

Heath, T.B., DelVecchio, D. \& McCarthy, M.S. 2011. 'The asymmetric effects of extending brands to lower and higher quality', Journal of Marketing, 75(4): 3-20.

Interbrand. 2015. 16th annual best global brands report. Retrieved from http://interbrand.com/newsroom/interbrand-releases-2015best-global-brands-report/

Japutra, A., Ekinci, Y. \& Simkin, L. 2014. 'Exploring brand attachment, its determinants and outcomes', Journal of Strategic Marketing, 22(7): 616-630.

Keller, K.L. 2001. 'Building customer-based brand equity: A blueprint for creating strong brands', Marketing Management, July/August: 15-19

Keller, K.L. 2014. 'Consumer brand relationships', Journal of Brand Management, 21(5): 365-365.
Keller, K.L. \& Lehmann, D.R. 2009. 'Assessing long-term brand potential', Journal of Brand Management, 17(1): 6-17.

Kim, C.K. \& Lavack, A.M. 1996. 'Vertical brand extensions: Current research and managerial implications', Journal of Product \& Brand Management, 5(6): 24-37.

Kim, C.K., Lavack, A.M. \& Smith, M. 2001. 'Consumer evaluation of vertical brand extensions and core brands', Journal of Business Research, 52(3): 211-222.

Kim, K., Park, J. \& Kim, J. 2014. 'Consumer brand relationship quality: When and how it helps brand extensions', Journal of Business Research, 67(4): 591-597.

Kirmani, A., Sood, S. \& Bridges, S. 1999. 'The ownership effect in consumer responses to brand line stretches', The Journal of Marketing, 63(January): 88-101.

Kotler, P. 2009. Marketing management: Analysis, planning, implementation and control. New Jersey: New Edition, Prentice Hall International Inc.

Kuenzel, S. \& Halliday, S.V. 2010. 'The chain of effects from reputation and brand personality congruence to brand loyalty: The role of brand identification', Journal of Targeting, Measurement and Analysis for Marketing, 18(3): 167-176.

Lee, J.G. 2015. Business statistics made easy in SAS (Vol. 1). Johannesburg: Silke Route Press.

Liu, C.M. 2002. 'The effects of promotional activities on brand decision in the cellular telephone industry', Journal of Product \& Brand Management, 11(1): 42-51.

MacInnis, D.J. 2012. 'Brands as intentional agents: Questions and extensions', Journal of Consumer Psychology, 22(2): 195-198.

Magnoni, F. \& Roux, E. 2008. Stretching the brand down: Does it affect consumer-brand relationship. Paper presented at the Proceedings of the Thought Leaders International Conference on Brand Management, Birmingham Business School.

Magnoni, F. \& Roux, E. 2012. 'The impact of step-down line extension on consumer-brand relationships: A risky strategy for luxury brands', Journal of Brand Management, 19(7): 595-608.

Morgan, R.M. 1991. Relationship commitment and trust in marketing, Doctoral Dissertation in Business Administration, Texas University. Retrieved from https://repositories.tdl.org/ttuir/bitstream/handle/2346/22168/31295007020125.pdf?sequence $=1$

Munthree, S., Bick, G. \& Abratt, R. 2006. 'A framework for brand revitalization through an upscale line extension', Journal of Product \& Brand Management, 15(3): 157-167.

Nijssen, E.J. 1999. 'Success factors of line extensions of fastmoving consumer goods', European Journal of Marketing, 33(5/6): 450-474.

Nueno, J.L. \& Quelch, J.A. 1998. 'The mass marketing of luxury', Business Horizons, 41(6): 61-68.

Phau, I., Min Teah, P., Hanslin, K. \& Rindell, A. 2014. 'Consumerbrand relationships in step-down line extensions of luxury and designer brands', Journal of Fashion Marketing and Management, 18(2): 145-168. 
Phau, I. \& Prendergast, G. 2000. 'Consuming luxury brands: The relevance of the "rarity principle", The Journal of Brand Management, 8(2): 122-138.

Pina, J.M., Martinez, E., De Chernatony, L. \& Drury, S. 2006. 'The effect of service brand extensions on corporate image: An empirical model', European Journal of Marketing, 40(1/2) 174-197.

Pitta, D.A. \& Prevel Katsanis, L. 1995. 'Understanding brand equity for successful brand extension', Journal of Consumer Marketing, 12(4): 51-64.

Rahman, K. \& Areni, C.S. 2014. 'Generic, genuine, or completely new? Branding strategies to leverage new products', Journal of Strategic Marketing, 22(1): 3-15.

Randall, T., Ulrich, K. \& Reibstein, D. 1998. 'Brand equity and vertical product line extent', Marketing Science, 17(4): 356-379.

Roets, C.R.Q., Bevan-Dye, A.L. \& Viljoen, W.P. 2014. 'Influence of social image and brand trust on mobile phone brand equity amongst African generation Y students', Mediterranean Journal of Social Sciences, 5(21): 75.

Sahin, A., Zehir, C. \& Kitapçı, H. 2011. 'The effects of brand experiences, trust and satisfaction on building brand loyalty: An empirical research on global brands', Procedia - Social and Behavioral Sciences, 24: 1288-1301.

Schmitt, B. 2012. 'The consumer psychology of brands', Journal of Consumer Psychology, 22(1): 7-17.

Shine, B.C., Park, J. \& Wyer Jr., R.S. 2007. 'Brand synergy effects in multiple brand extensions', Journal of Marketing Research, 44(4): 663-670.

Song, P., Zhang, C., Xu, Y.C. \& Huang, L. 2010. 'Brand extension of online technology products: Evidence from search engine to virtual communities and online news', Decision Support Systems, 49(1): 91-99.

Statistics-SouthAfrica. 2014. Mid-year population estimates 2014 [Press release]. Retrieved from http://www.statssa.gov.za/?p=2990.

Stokburger-Sauer, N., Ratneshwar, S. \& Sen, S. 2012. 'Drivers of consumer-brand identification', International Journal of Research in Marketing, 29(4): 406-418.

Sundie, J.M., Kenrick, D.T., Griskevicius, V., Tybur, J.M., Vohs, K.D. \& Beal, D.J. 2011. 'Peacocks, Porsches, and Thorstein Veblen: Conspicuous consumption as a sexual signaling system', Journal of Personality and Social Psychology, 100(4): 664.

Torelli, C.J., Özsomer, A., Carvalho, S.W., Keh, H.T. \& Maehle, N. 2012: 'Brand concepts as representations of human values: Do cultural congruity and compatibility between values matter?', Journal of Marketing, 76(4): 92-108.

Tuškej, U., Golob, U. \& Podnar, K. 2013. 'The role of consumerbrand identification in building brand relationships', Journal of Business Research, 66(1): 53-59.

UNICEF. 2012. South Africa mobile generation: Study of South African young people on mobiles. Retrieved from http://www.unicef.org/southafrica/resources_10782.html
Vukasovič, T. 2012. 'Searching for competitive advantage with the brand extension process', Journal of Product \& Brand Management, 21(7): 492-498.

Warrington, P. \& Shim, S. 2000. 'An empirical investigation of the relationship between product involvement and brand commitment', Psychology \& Marketing, 17(9): 761-782.

WorldBank. 2013. World Bank South Africa data. Retrieved from http://data.worldbank.org/country/south-africa. 